\title{
Central role of nitric oxide in the pathogenesis of rheumatoid arthritis and systemic lupus erythematosus
}

\author{
György Nagy*1,2, Agnes Koncz², Tiffany Telarico ${ }^{3}$, David Fernandez³ ${ }^{3}$ Barbara Érsek², Edit Buzás² and András Perl ${ }^{3}$
}

\begin{abstract}
Nitric oxide (NO) has been shown to regulate T cell functions under physiological conditions, but overproduction of NO may contribute to T lymphocyte dysfunction. NO-dependent tissue injury has been implicated in a variety of rheumatic diseases, including systemic lupus erythematosus (SLE) and rheumatoid arthritis (RA). Several studies reported increased endogenous NO synthesis in both SLE and RA, and recent evidence suggests that $\mathrm{NO}$ contributes to $T$ cell dysfunction in both autoimmune diseases. The depletion of intracellular glutathione may be a key factor predisposing patients with SLE to mitochondrial dysfunction, characterized by mitochondrial hyperpolarization, ATP depletion and predisposition to death by necrosis. Thus, changes in glutathione metabolism may influence the effect of increased NO production in the pathogenesis of autoimmunity.
\end{abstract}

\section{Basic functions of nitric oxide}

Nitric oxide (NO) is a short-lived signaling molecule that plays an important role in a variety of physiologic functions, including the regulation of blood vessel tone, inflammation, mitochondrial functions and apoptosis $[1,2]$. NO was originally identified as endotheliumderived relaxant factor based on the observations of Furchgott and Zawadzki [3]. They observed that acethylcholine-induced blood vessel relaxation occurred only if the endothelium was intact. Some years later, the endothelium-derived relaxant factor was identified as $\mathrm{NO}$ [4]. NO is synthesized from L-arginine by NO synthetases (NOSs): neuronal NOS (nNOS), inducible

*Correspondence: gyorgyngy@gmail.com

'Department of Rheumatology, Semmelweis University, Medical School, Árpád fejedelem út 7, Budapest, Hungary

Full list of author information is available at the end of the article
NOS (iNOS), and endothelial NOS (eNOS) [5]. NO also serves as a potent immunoregulatory factor, and influences the cytoplasmic redox balance through the generation of peroxynitrite $\left(\mathrm{ONOO}^{-}\right)$following its reaction with superoxide $\left(\mathrm{O}_{2}^{-}\right)$[6]. In addition, NO regulates signal transduction by regulating $\mathrm{Ca}^{2+}$ signaling, by regulating the structure of the immunological synapse, or through the modification of intracellular proteins, such as by interactions with heme groups (Figure 1). Here we summarize the effects of $\mathrm{NO}$ on $\mathrm{T}$ lymphocyte functions in both systemic lupus erythematosus (SLE) and rheumatoid arthritis (RA).

NO regulates mitochondrial membrane potential in human $\mathrm{T}$ cells [7], and may both stimulate and inhibit apoptosis [8]. It was shown to inhibit cytochrome c oxidase, leading to cell death through ATP depletion (Figure 1). In addition, NO was shown to regulate mitochondrial biogenesis in U937 and HeLa cells and adipocytes through the cGMP-dependent peroxisome proliferator-activating receptor $\lambda$ coactivator $1 \alpha$ [9]. According to our earlier work, NO regulates mitochondrial biogenesis in human lymphocytes as well [10]. Nitrosylation of sulfhydryl groups represents an important cGMP-independent, NO-dependent post-translational modification. Several important signal transduction proteins are potential targets of S-nitrosylation, such as caspases and c-Jun-N-terminal kinase (JNK) $[11,12]$.

\section{The role of nitric oxide in $\mathrm{T}$ cell activation and differentiation}

NO regulates $\mathrm{T}$ lymphocyte function in several ways: $\mathrm{T}$ cell activation is associated with $\mathrm{NO}$ production and mitochondrial hyperpolarization (MHP) [13]. According to our previous data, eNOS and nNOS are expressed in human peripheral blood lymphocytes and both are upregulated several times following $\mathrm{T}$ cell activation [13]. TCR stimulation induces $\mathrm{Ca}^{2+}$ influx and, through inositol-1,4,5-triphosphate ( $\left.\mathrm{IP}_{3}\right)$, the release of $\mathrm{Ca}^{2+}$ from intracellular stores. The $\mathrm{IP}_{3}$ inhibitor 2-APB (2-aminoethoxydiphenyl borane) decreases T-cellactivation-induced $\mathrm{Ca}^{2+}$ and $\mathrm{NO}$ production, and $\mathrm{NO}$ 


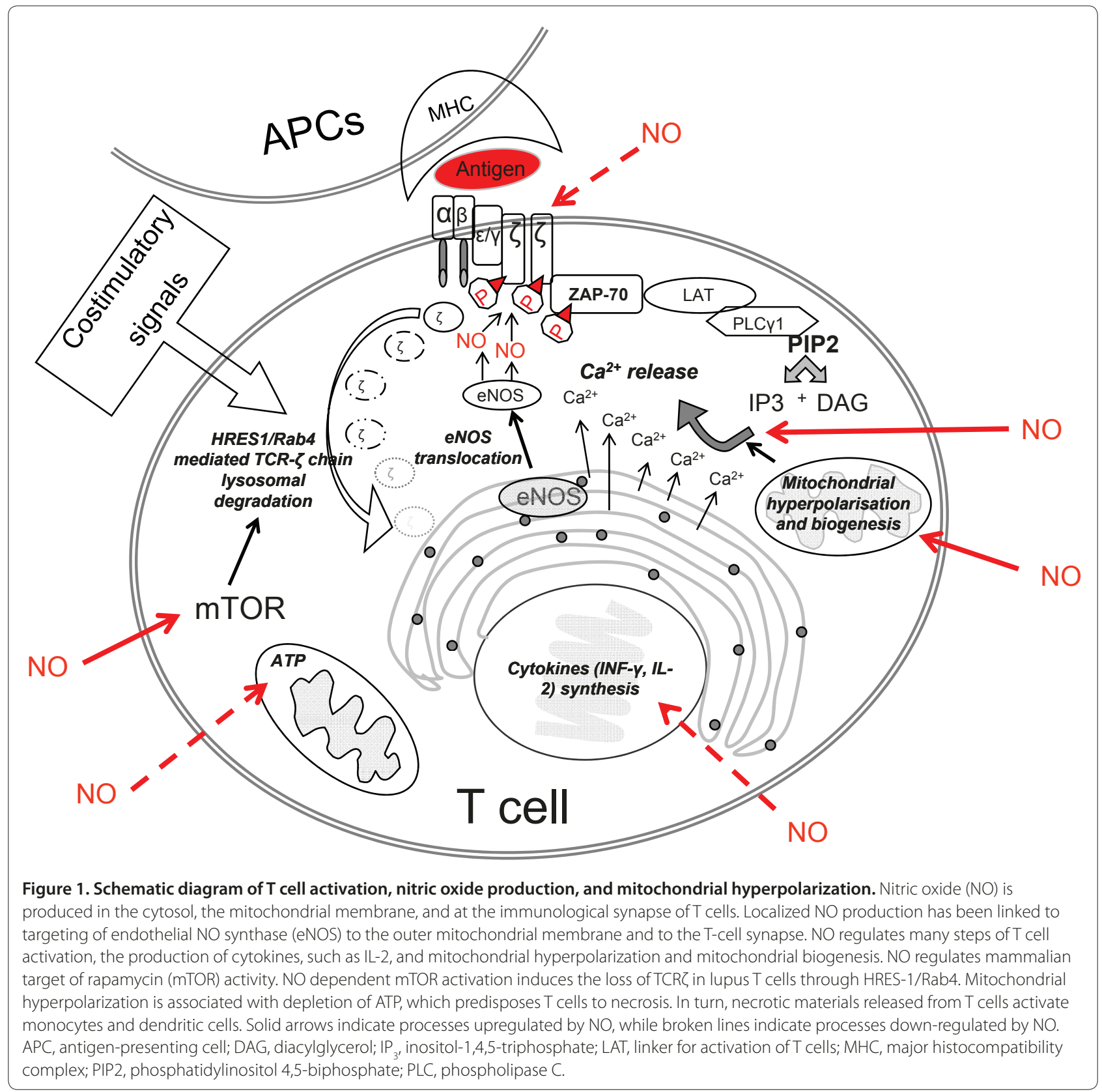

treatment of $\mathrm{T}$ lymphocytes leads to an increase in mitochondrial and cytoplasmic $\mathrm{Ca}^{2+}$ levels. In contrast, the NO chelator C-PTIO (carboxy-2-phenyl-4,4,5,5-tetramethyl-imidazoline-1-oxyl-3-oxide) powerfully inhibits the T-cell-activation-induced $\mathrm{Ca}^{2+}$ response, NO production and MHP, indicating that $\mathrm{T}$ cell receptor (TCR)activation-induced MHP is mediated by NO [13].

A central event in the antigen-specific interaction of $\mathrm{T}$ cells with antigen-presenting cells is the formation of the immunological synapse, in which the TCR complex and the adhesion receptor LFA-1 (leukocyte functionassociated antigen 1) are organized in central and peripheral supramolecular activation clusters. eNOS was shown to translocate with the Golgi apparatus to the immune synapse of $\mathrm{T}$ helper cells engaged with antigenpresenting cells [14] (Figure 1). Overexpression of eNOS was associated with increased phosphorylation of the

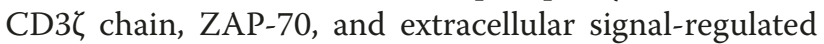
kinases, and increased IFN- $\gamma$ synthesis, but reduced production of IL-2. These data indicate that eNOS-derived NO selectively potentiates $\mathrm{T}$ cell receptor signaling to antigen at the immunological synapse [14].

Following activation, CD4 $\mathrm{T}$ cells proliferate and differentiate into two main subsets of primary effector 
cells, T helper 1 (Th1) and Th2 cells, characterized by their specific cytokine expression patterns [15]. The Th1/ Th2 balance is considered to be essential in chronic inflammatory diseases. NO selectively enhances Th1 cell proliferation [16] and represents an additional signal for the induction of $\mathrm{T}$ cell subset response. According to our data, the NO precursor NOC-18 elicited IFN- $\gamma$ production, whereas the $\mathrm{NO}$ synthase inhibitors $\mathrm{N}^{\mathrm{G}}$-monomethyl-L-arginine and nitronidazole both inhibited its production, suggesting a role for $\mathrm{NO}$ in regulating IFN- $\gamma$ synthesis [17]. NO preferentially promotes IFN- $\gamma$ synthesis and type Th1 cell differentiation by selective induction of IL-12R $\beta 2$ via cGMP. Together, these data indicate that NO has a crucial role in the regulation of Th1/Th2 polarization.

\section{Nitric oxide regulates $\mathrm{T}$ lymphocyte activation in systemic lupus erythematosus}

Considerable evidence supports that NO production is increased in SLE; for example, serum nitrite and nitrate levels were recently reported to correlate with disease activity and damage in SLE [18]. According to our previous work, NO plays a crucial role in $\mathrm{T}$ cell dysregulation in SLE [19-21]. Activation-induced rapid $\mathrm{Ca}^{2+}$ signals are higher in T cells from patients with SLE [22]; in contrast, the sustained $\mathrm{Ca}^{2+}$ signal is decreased in these lupus $\mathrm{T}$ cells. Interestingly, the mitochondrial membrane potential is permanently high in lupus T cells [23-25]. Lupus and normal $\mathrm{T}$ cells produce comparable amounts of NO, but monocytes from lupus patients generate significantly more NO than normal monocytes. As it is a diffusible gas, NO produced by neighboring cells may affect $\mathrm{T}$ cell functions. Accordingly, NO produced by monocytes contributes to lymphocyte mitochondrial dysfunction in SLE [10]. Peripheral blood lymphocytes from SLE patients contain enlarged mitochondria, and as there are microdomains between mitochondria and the endoplasmic reticulum and because mitochondria may also serve as $\mathrm{Ca}^{2+}$ stores, this increased mitochondrial mass may alter $\mathrm{Ca}^{2+}$ signaling in SLE $[10,26]$. Although NO production was found to be increased in both lupus [10] and RA [27], MHP was confined to lupus T cells $[10,13,28,29]$. This difference may be attributed to the depletion of intracellular glutathione (GSH) in SLE but not in RA or healthy controls [28]. Indeed, low GSH predisposes to MHP in human T cells, as originally described by Banki and colleagues [30]. Increased exposure to IFN may contribute to the increased NO production of lupus monocytes [31].

\section{NO regulates mammalian target of rapamycin activity and TCR expression in SLE}

The mammalian target of rapamycin (mTOR) is a serine/ threonine protein kinase and a sensor of the mitochondrial transmembrane potential that regulates protein synthesis, cell growth, cell proliferation and survival [32]. The activity of mTOR is increased in lupus $\mathrm{T}$ cells [29] (Table 1); furthermore, NO regulates mTOR activity, which leads to enhanced expression of HRES-1/ Rab4, a small GTPase that regulates recycling of surface receptors through early endosomes [29,33]. HRES-1/ Rab4 overexpression inversely correlates with TCR $\zeta$ protein levels. TCR/CD3 expression is regulated by TCR $\zeta$, and diminished $\zeta$ chain expression disrupts TCR transport and function [34]. The TCR $\zeta$ chain is deficient in lupus $\mathrm{T}$ cells $[35,36]$, although this deficiency has been shown to be independent of SLE disease activity $[37,38]$. Sequencing of genomic DNA and TCR $\zeta$ transcripts showed mutations in the coding region of TCR $\zeta$ from lupus $\mathrm{T}$ cells [39]. There is a direct interaction between HRES-1/Rab4, CD4 and TCR $\zeta$. Rapamycin treatment of lupus patients reversed the TCR $\zeta$ deficiency of lupus $\mathrm{T}$ cells, and normalized T-cell-activation-induced calcium fluxing [29]. These data suggest that NO-dependent mTOR activation induces the loss of TCR $\zeta$ in lupus $\mathrm{T}$ cells through HRES-1/Rab4. Several earlier findings indicate that decreased TCR $\zeta$ chain expression may also be independent of NO in SLE [40-44].

\section{Consequences of increased nitric oxide production in rheumatoid arthritis}

Several studies in patients with RA have documented evidence for increased endogenous NO synthesis, suggesting that overproduction of NO may be important in the pathogenesis of RA. The inflamed joint in RA is the predominant source of NO $[45,46]$. Several investigators found correlations between serum nitrite concentration and RA disease activity or radiological progression while others did not find such correlations [47,48]. NOS polymorphism has been observed in RA [49]. iNOS is regulated at the transcriptional level, while eNOS and nNOS are regulated by intracellular $\mathrm{Ca}^{2+}$. Several different cell types are capable of generating NO in the inflamed synovium, including osteoblasts, osteoclasts, macrophages, fibroblasts, neutrophils and endothelial cells [50-52]. NOS inhibition was reported to decrease disease activity in experimental RA [53].

We have shown recently that $\mathrm{T}$ cells from RA patients produce more than 2.5 times more NO than healthy donor T cells $(P<0.001)$ [27]. Although NO is an important physiological mediator of mitochondrial biogenesis, mitochondrial mass is similar in both RA and control $\mathrm{T}$ cells (Table 1). By contrast, increased NO production is associated with increased cytoplasmic $\mathrm{Ca}^{2+}$ concentrations in RA T cells $(P<0.001)$. Furthermore, in vitro treatment of human peripheral blood lymphocytes or Jurkat cells with TNF increases NO production $(P=0.006$ and $P=0.001$, respectively), whilst infliximab treatment 
Table 1. Nitric oxide-induced T cell functions in sysemic lupus erythematosus and rheumatoid arthritis

\begin{tabular}{lll}
\hline Altered T cell function & SLE & RA \\
\hline Mitochondrial hyperpolarization and biogenesis & Higher [10] & Normal [27] \\
Tlymphocyte NO production & Normal [10] & Increased [27] \\
TCR-induced rapid and sustained Ca ${ }^{2+}$ signal & Rapid-increased, sustained-decreased [10] & Decreased [61] \\
TCR expression & Decreased [34] & Not known \\
mTOR activity & Increased [29] & Normal [28] \\
ATP level & Decreased [28] & Increased [46] \\
\hline Monocyte NO production & Increased [10] & \\
\hline
\end{tabular}

mTOR, mammalian target of rapamycin; NO, nitric oxide; RA, rheumatoid arthritis; SLE, systemic lupus erythematosus; TCR, T cell antigen receptor.

of RA patients decreases T-cell-derived NO production within 6 weeks of the first infusion $(P=0.005)$ [27]. Increased NO production of monocytes is associated with increased mitochondrial biogenesis in lupus $\mathrm{T}$ cells, while increased NO production of $\mathrm{T}$ cells is not associated with increased mitochondrial mass in RA. Monocytes express iNOS, while lymphocytes express both eNOS and nNOS. Although NO is generated more rapidly via the eNOS or nNOS than the iNOS pathway, iNOS can generate much larger quantities of NO than eNOS and nNOS. Thus, the lower amount of NO generated by $\mathrm{T}$ cells compared to monocytes may explain the differences in $\mathrm{T}$ lymphocyte mitochondrial biogenesis that we observed for lupus and RA T cells.

iNOS knockout mice are resistant to IL-1-induced bone resorption, suggesting that NO plays a central role in the pathogenesis of bone erosions in RA [51,54]. TNF blockade decreases iNOS expression in human peripheral blood mononuclear cells [55]. Tripterygium wilfordii Hook F (TWHF) was also reported to be effective in the treatment of experimental arthritis [56]. The specific inhibition of iNOS by TWHF is probably responsible for the anti-inflammatory effects of this medicinal plant. NO treatment may lead to necrosis rather than apoptosis by decreasing intracellular ATP levels. The release of intracellular antigens through necrosis may accelerate autoimmune reactions leading to chronic inflammation $[57,58]$.

\section{Oxidative stress and TCR expression in RA T cells - the possible role of NO}

Reduced GSH levels may contribute to the hyporesponsiveness of $\mathrm{T}$ cells from synovial fluid of RA patients $[59,60]$. The expression of the TCR $\zeta$ chain protein is decreased in synovial fluid T cells of RA patients, similar to lupus $\mathrm{T}$ cells, which may contribute to the abovementioned hyporesponsiveness of the synovial fluid $\mathrm{T}$ cells [61]. TNF- $\alpha$ treatment decreases TCR $\zeta$ chain expression of T cells [62] in a GSH-precursor-sensitive way, showing the role of redox balance in the regulation of TCR $\zeta$ chain expression. TCR $\zeta$ overexpression does not restore signaling in TNF- $\alpha$-treated $\mathrm{T}$ cells [63]. Increased NO production may alter redox balance through generating peroxynitrite following its reaction with superoxide. In this way NO may contribute to the decreased TCR $\zeta$ chain expression of $\mathrm{T}$ lymphocytes from synovial fluid [61]. Importantly, FcR gamma substitutes for the TCR $\zeta$ chain in SLE T cells [64], which may explain the enhanced T-cell-activation-induced $\mathrm{Ca}^{2+}$ fluxing. The potential role of $\mathrm{NO}$ in the regulation of FCR gamma expression clearly needs further investigation.

\section{Th17 and regulatory $\mathrm{T}$ cells}

Recently, the Th1/Th2 paradigm has been updated following the discovery of a third subset of Th cells, known as Th17 cells. Th17 cells have been identified as cells induced by IL- 6 and TGF- $\beta$ and expanded by IL-23 [65]. Similarly to Th1 and Th2 subsets, Th17 development relies on the action of a lineage-specific transcription factor. Th17 cells have emerged as an independent subset because their differentiation was independent of the Th1 and Th2 promoting transcription factors T-bet, STAT1, STAT4 and STAT6. ROR- $\gamma \mathrm{t}$, ROR $\alpha$ and STAT3 appear to be critical for the development of Th17 cells. Th17 cells produce IL-17 and are thought to clear extracellular pathogens that are not effectively handled by either Th1 or Th2 cells, and have also been strongly implicated in allergic diseases [66]. In addition to IL-17, Th17 cells produce other proinflammatory cytokines such as IL-21 and IL-22. Increased levels of IL-17 have been observed in patients with RA. Indeed, IL-17 can directly and indirectly promote cartilage and bone destruction. IL-17deficient mice develop attenuated collagen-induced arthritis. The role of NO in IL- 6 - and TGF- $\beta$-induced Th17 cell differentiation has not been studied yet.

Regulatory $\mathrm{T}$ cells (Tregs) represent a subset of $\mathrm{T}$ cells involved in peripheral immune tolerance. There are at least three major types of Tregs with overlapping functions: Th3, Treg1, and CD $4{ }^{+} \mathrm{CD} 25^{+}$Tregs. CD $4{ }^{+} \mathrm{CD} 25^{+}$ Tregs (naturally occurring cells or nTREGs) are the best characterized, principally because it is relatively easy to obtain large numbers of these cells. Tregs seem to have 
an impaired regulatory function in RA. It was recently reported that $\mathrm{NO}$, together with anti-CD3, induces the proliferation and sustained survival of mouse $\mathrm{CD} 4{ }^{+} \mathrm{CD} 25$ $\mathrm{T}$ cells, which became $\mathrm{CD} 4{ }^{+} \mathrm{CD} 25^{+}$but remained Foxp3This previously unrecognized population of Tregs (NO-Tregs) downregulated the proliferation and function of freshly purified $\mathrm{CD} 4{ }^{+} \mathrm{CD} 25^{-}$effector cells in vitro and suppressed colitis- and collagen-induced arthritis in mice in an IL-10-dependent manner [67]. The existence of human NO-Tregs has not been investigated yet. Although NO profoundly alters $\mathrm{T}$ cell activation and Th1/Th2 balance, the precise role of NO in Th17 and Treg differentiation is not known.

\section{Conclusion}

Whilst NO plays a central role in many physiological processes, its increased production is pathological. NO mediates many different cell functions at the site of synovial inflammation, including cytokine production, signal transduction, mitochondrial functions and apoptosis (Table 1). The effects of NO depend on its concentration. Increased NO production plays an important role in the pathogenesis of both SLE and RA. Further studies are needed to determine the cellular and molecular mechanisms by which NO regulates immune cell functions. NOS inhibition may represent a novel therapeutic approach in the treatment of chronic autoimmune diseases.

\section{Abbreviations}

eNOS = endothelial NOS; GSH = glutathione; IFN = interferon; IL = interleukin; iNOS = inducible NOS; $\mathrm{PP}_{3}=$ inositol-1,4,5-triphosphate; $\mathrm{MHP}=$ mitochondrial hyperpolarization; $\mathrm{mTOR}^{3}=$ mammalian target of rapamycin; $\mathrm{nNOS}=$ neuronal $\mathrm{NOS} ; \mathrm{NO}=$ nitric oxide; $\mathrm{NOS}=\mathrm{NO}$ synthase; $\mathrm{RA}=$ rheumatoid arthritis; $\mathrm{SLE}=$ systemic lupus erythematosus; $\mathrm{TCR}=\mathrm{T}$ cell antigen receptor; $\mathrm{TGF}=$ transforming growth factor; $\mathrm{Th}=\mathrm{T}$ helper; $\mathrm{TNF}=$ tumor necrosis factor; Treg = regulatory $\mathrm{T}$ cell; $\mathrm{TWHF}=$ Tripterygium wilfordii Hook F.

\section{Competing interests}

The authors declare that they have no competing interests.

\section{Acknowledgements}

This work has been supported by grants RO1 Al 048079 and Al 072678 from the National Institutes of Health, the Alliance for Lupus Research, the Central New York Community Foundation, as well as OTKA K77537 and OTKA K73247. György Nagy is a Bolyai Research fellow.

\section{Author details}

'Department of Rheumatology, Semmelweis University, Medical School, Budapest, Hungary. ${ }^{2}$ Department of Genetics, Cell and Immunobiology, Semmelweis University, Medical School, Budapest, Hungary. ${ }^{3}$ Departments of Medicine, Pathology, and Microbiology and Immunology, State University of New York, College of Medicine, 750 East Adams Street, Syracuse, NY 13210, USA.

\section{Published: 28 June 2010}

\section{References}

1. Brown-CG: Nitric oxide and mitochondrial respiration. Biochem Biophys Acta 1999, 1411:351-369.

2. Beltran B, Mathur A, Duchen MR, Erusalimsky JD and Moncada S: The effect of nitric oxide on cell respiration: a key to undertanding its role in cell survival, or death. Proc Natl Acad Sci U S A 2000, 26:14602-14607.
3. Furchgott RF, Zawadzki JV: The obligatory role of endothelial cells in the relaxation of arterial smooth muscle by acetylcholine. Nature 1980, 288:373-376.

4. Palmer RM, Ferrige AG, Moncada S: Nitric oxide release accounts for the biological activity of endothelium-derived relaxing factor. Nature 1987, 327:524-526.

5. Bredt DS: Endogenous nitrice oxide synthesis: biological functions and pathophysiology. Free Radic Res 1999, 31:577-596.

6. Chung HT, Pae HO, Choi BM, Billiar TR, Kim YM: Nitric oxide as a bioregulator of apoptosis. Biochem Biophys Res Commun 2001, 282:1075-1079.

7. Beltran B, Quintero M, Gracia-Zaragoza E, O'Connor E, Espluques JV, Moncada S: Inhibition of mitochondrial respiration by endogenous nitric oxide: a critical step in Fas signalling. Proc Natl Acad Sci U S A 2002, 13:8892-8897.

8. Kim YM, B Ombeck CA, Billiar TR: Nitric oxide as a bifunctional regulator of apoptosis. Circ Res 1999, 19:253-256.

9. Nisoli E, Clementi E, Paolucci C: Mitochondrial biogenesis in mammals: the role of endogenous nitric oxide. Science 2003, 299:896-899.

10. Nagy G, Barcza M, Gonchoroff N, Phillips PE, Perl A: Nitric oxide-dependent mitochondrial biogenesis generates $\mathrm{Ca} 2+$ signaling profile of lupus $\mathrm{T}$ cells. $J$ Immunol 2004, 173:3676-3683.

11. Mallis RJ, Buss JE, Thomas JA: Oxidative modification of H-ras: S-thiolation and S-nitrosylation of reactive cysteines. Biochem J 2001, 355:145-153.

12. Gow AJ, Farkouh CR, Munson DA, Posencheg MA, Ischiropoulos H: Biological significance of nitric oxide-mediated protein modifications. Am J Physiol Lung Cell Mol Physiol 2004, 287:L262-268.

13. Nagy G, Koncz A, Perl A: T cell activation-induced mitochondrial hyperpolarization is mediated by $\mathrm{Ca} 2+-$ and redox-dependent production of nitric oxide. J Immunol 2003, 171:5188-5197.

14. Ibiza S, Víctor VM, Boscá I, Ortega A, Urzainqui A, O'Connor JE, SánchezMadrid F, Esplugues JV, Serrador JM: Endothelial nitric oxide synthase regulates $T$ cell receptor signaling at the immunological synapse. Immunity 2006, 24:753-765.

15. Skapenko A, Leipe J, Lipsky PE, Schulze-Koops $\mathrm{H}$ : The role of the T cell in autoimmune inflammation. Arthritis Res Ther 2005, 7 Suppl 2:S4-14.

16. Niedbala W, Wei XQ, Campbell C, Thomson D, Komai-Koma M, Liew FY: Nitric oxide preferentially induces type $1 \mathrm{~T}$ cell differentiation by selectively up-regulating IL-12 receptor beta 2 expression via cGMP. Proc Natl Acad SCI USA 2002, 99:16186-16191.

17. Koncz A, Pasztoi M, Mazan M, Fazakas F, Buzas E, Falus A, Nagy G: Nitric oxide mediates $\mathrm{T}$ cell cytokine production and signal transduction in histidine decarboxylase knockout mice. J Immunol 2007, 179:6613-6619.

18. Oates JC, Shaftman SR, Self SE, Gilkeson GS: Association of serum nitrate and nitrite levels with longitudinal assessments of disease activity and damage in systemic lupus erythematosus and lupus nephritis. Arthritis Rheum 2008, 58:263-272.

19. Nagy G, Koncz A, Philips PE, Perl A: Mitochondrial signal transduction abnormalities in systemic lupus erythematosus. Curr Immunol Rev 2005, 1:61-67.

20. Perl A: Emerging new pathways of pathogenesis and targets for treatment in systemic lupus erythematosus and Sjogren's syndrome. Curr Opin Rheumatol 2009, 21:443-447.

21. Perl A, Fernandez DR, Telarico T, Doherty E, Francis L, Phillips PE: T-cell and B-cell signaling biomarkers and treatment targets in lupus. Curr Opin Rheumatol 2009, 21:454-464.

22. Vassilopoulos D, Kovacs B, Tsokos GC: TCR/CD3 complex-mediated signal transduction pathway in T cells and $T$ cell lines from patients with systemic lupus erythematosus. J Immunol 1995, 155:2269-2281.

23. Perl A, Gergely P Jr, Nagy G, Koncz A, Banki K: Mitochondrial hyperpolarization: a checkpoint of T-cell life, death and autoimmunity. Trends Immunol 2004, 25:360-367.

24. Perl A, Nagy G, Gergely P, Puskas F, Qian Y, Banki K: Apoptosis and mitochondrial dysfunction in lymphocytes of patients with systemic lupus erythematosus. Methods Mol Med 2004, 102:87-114

25. Kammer GM, Perl A, Richardson BC, Tsokos GC: Abnormal T cell signal transduction in systemic lupus erythematosus. Arthritis Rheum 2002, 46:1139-1154.

26. Rizutto R, Duchen MR, Pozzan T: Flirting in little space: the ER/mitochondrial Ca2+ liaison. SciSTKE 2004, 13:215-217.

27. Nagy G, Clark JM, Buzas E, Gorman C, Pasztoi M, Koncz A, Falus A, Cope AP: Nitric oxide production of $\mathrm{T}$ lymphocytes is increased in rheumatoid arthritis. Immunol Lett 2008, 118:55-58. 
28. Gergely P Jr, Grossman C, Niland B, Puskas F, Neupane H, Allam F, Banki K, Phillips PE, Perl A: Mitochondrial hyperpolarization and ATP depletion in patients with systemic lupus erythematosus. Arthritis Rheum 2002, 46:175-190.

29. Fernandez DR, Telarico T, Bonilla E, Li Q, Banerjee S, Middleton FA, Phillips PE, Crow MK, Oess S, Muller-Esterl W, Perl A: Activation of mammalian target of rapamycin controls the loss of TCRzeta in lupus T cells through HRES-1/ Rab4-regulated lysosomal degradation. J Immunol 2009, 182:2063-2073.

30. Banki K, Hutter E, Gonchoroff NJ, Perl A: Elevation of mitochondrial transmembrane potential and reactive oxygen intermediate levels are early events and occur independently from activation of caspases in Fas signaling. J Immuno/ 1999, 162:1466-1479.

31. Bauer JW, Petri M, Batliwalla FM, Koeuth T, Wilson J, Slattery C, PanoskaltsisMortari A, Gregersen PK, Behrens TW, Baechler EC: Interferon-regulated chemokines as biomarkers of systemic lupus erythematosus disease activity: a validation study. Arthritis Rheum 2009, 60:3098-3107.

32. Hay N, Sonenberg N: Upstream and downstream of mTOR. Genes Dev 2004 18:1926-1945

33. Nagy G, Ward J, Mosser DD, Koncz A, Gergely P Jr, Stancato C, Qian Y, Fernandez D, Niland B, Grossman CE, Telarico T, Banki K, Perl A: Regulation of CD4 expression via recycling by HRES-1/RAB4 controls susceptibility to HIV infection. J Biol Chem 2006, 281:34574-34591.

34. Kirchgessner H, Dietrich J, Scherer J, Isomäki P, Korinek V, Hilgert I, Bruyns E, Leo A, Cope AP, Schraven B: The transmembrane adaptor protein TRIM regulates $T$ cell receptor (TCR)expression and TCR-mediated signaling via an association with the TCR zeta chain. J Exp Med 2001, 193:1269-1284.

35. Liossis SNC, Ding XZ, Dennis GJ, Tsokos GC: Altered pattern of TCR/CD3 mediated protein tyrosyl phosphorylation in T cells from patients with systemic lupus erythematosus: deficient expression of the T cell receptor zeta chain. J Clin Invest 1998, 101:1448-1457.

36. Brundula V, Rivas LJ, Blasini AM, París M, Salazar S, Stekman IL, Rodríguez MA Diminished levels of T cell receptor $\zeta$ chains in peripheral blood T lymphocytes from patients with systemic lupus erythematosus. Arthritis Rheum 1999, 42:1908-1916.

37. Nambiar MP, Mitchell JP, Ceruti RP, Mally MA, Tsokos GC: Prevalence of T cell receptor zeta chain deficiency in systemic lupus erythematosus. Lupus 2003, 12:46-51

38. Nambiar MP, Enyedi EJ, Fisher CU, Warke VG, Juang YT, Tsokos GC: Dexamethasone modulates TCR zeta chain expression and antigen receptor-mediated early signaling events in human T lymphocytes. Cell Immunol 2001, 208:62-71.

39. Nambiar MP, Enyedy EJ, Warke VG, Krishnan S, Dennis G, Wong HK, Kammer GM, Tsokos GC: T cell signaling abnormalities in systemic lupus erythematosus are associated with increased mutations/polymorphisms and splice variants of T cell receptor zeta chain messenger RNA. Arthritis Rheum 2001, 44:1336-1350.

40. Juang YT, Tenbrock K, Nambiar MP, Gourley MF, Tsokos GC: Defective production of functional $98-\mathrm{kDa}$ form of Elf- 1 is responsible for the decreased expression of TCR zeta-chain in patients with systemic lupus erythematosus. J Immuno/ 2002, 169:6048-6055.

41. Tenbrock K, Kyttaris VC, Ahlmann M, Ehrchen JM, Tolnay M, Melkonyan H, Mawrin C, Roth J, Sorg C, Juang YT, Tsokos GC: The cyclic AMP response element modulator regulates transcription of the TCR zeta-chain. J Immunol 2005, 175:5975-5980.

42. Chowdhury B, Tsokos CG, Krishnan S, Robertson J, Fisher CU, Warke RG, Warke VG, Nambiar MP, Tsokos GC: Decreased stability and translation of T cell receptor zeta mRNA with an alternatively spliced 3'-untranslated region contribute to zeta chain down-regulation in patients with systemic lupus erythematosus. J Bio/ Chem 2005, 280:18959-18966.

43. Krishnan S, Juang YT, Chowdhury B, Magilavy A, Fisher CU, Nguyen $\mathrm{H}_{\text {, }}$ Nambiar MP, Kyttaris V, Weinstein A, Bahjat R, Pine P, Rus V, Tsokos GC: Differential expression and molecular associations of Syk in systemic lupus erythematosus T cells. J Immunol 2008, 181:8145-8152.

44. Moulton VR, Tsokos GC: Alternative splicing factor/splicing factor 2 regulates the expression of the zeta subunit of the human $T$ cell receptorassociated CD3 complex. J Bio/ Chem 2010, 285:12490-12496.

45. Farrell AJ, Blake DR, Palmar RMJ: Increased concentrations of nitrite in synovial fluid and serum samples suggest increased nitric oxide synthesis in rheumatic diseases. Ann Rheum Dis 1992, 51:1219-1222.

46. Pham TN, Rahman P, Tobin YM, Khraishi MM, Hamilton SF, Alderdice C, Richardson $\mathrm{VJ}$ : Elevated serum nitric oxide levels in patients with inflammatory arthritis associated with co-expression of inducible nitric oxide synthase and protein kinase C-eta in peripheral blood monocytederived macrophages. J Rheumatol 2003, 30:2529-2534.

47. Onur O, Akinci AS, Akbiyik F, Unsal I: Elevated levels of nitrate in rheumatoid arthritis. Rheumatol Int 2001, 20:154-158.

48. Choi JW: Nitric oxide production is increased in patients with rheumatoid arthritis but does not correlate with laboratory parameters of disease activity. Clin Chim Acta 2003, 336:83-87.

49. Gonzalez-Gay MA, Llorca J, Sanchez E, Lopez-Nevot MA, Amoli MM, GarciaPorrua C, Ollier WE, Martin J: Inducible but not endothelial nitric oxide synthase polymorphism is associated with susceptibility to rheumatoid arthritis in northwest Spain. Rheumatology (Oxford) 2004, 43:1182-1185.

50. Firestein GS, Budd RC, Harris ED Jr, McInnes IB, Ruddy S, Sergent JS: Kelley's Textbook of Rheumatology. 7th edn. Elsevier, Saunders; 2005.

51. van't Hof RJ, Ralston SH: Nitric oxide and bone. Immunology 2001, 103:255-261.

52. Nagy G, Clark JM, Buzás El, Gorman CL, Cope AP: Nitric oxide, chronic inflammation and autoimmunity. Immuno/ Lett 2007, 111:1-5.

53. McCartney-francis N, Allen BJ, Mizel DE: Suppression of arthritis by an inhibitor of nitrice oxide synthase. J Exp Med 1993, 178:749-754.

54. van't Hof RJ, Armour KJ, Smith LM, Armour KE, Wei XQ, Liew FY, Ralston SH: Requirement of the inducible nitric oxide synthase pathway for IL-1induced osteoclastic bone resorption. Proc Natl Acad Sci U S A 2000, 97:7993-7998.

55. Perkins DJ, St Clair EW, Misukonis MA, Weinberg JB: Reduction of NOS2 overexpression in rheumatoid arthritis patients treated with anti-tumor necrosis factor alpha monoclonal antibody (cA2). Arthritis Rheum 1998, 41:2205-2210.

56. Wang $B, M a L, T a o X$, Lipsky PE: Triptolide, an active component of the Chinese herbal remedy Tripterygium wilfordii Hook F, inhibits production of nitric oxide by decreasing inducible nitric oxide synthase gene transcription. Arthritis Rheum 2004, 50:2995-2303.

57. Leist $M$, Single $B$, Castoldi AF, Kuhnle S, Nicotera P. Intracellular adenisine triphosphate (ATP) concentration: a switch in the decision between apoptosis and necrosis. J Exp Med 1997, 185:1481-1486.

58. Melino G, Catani MV, Corazzari M, Guerrieri P, Bernassola F: Nitric oxide can inhibit apoptosis or switch it into necrosis. Cell Mol Life Sci 2000, 57:612-622.

59. Maurice MM, Nakamura $H$, van der Voort EA, van Vliet Al, Staal FJ, Tak PP, Breedveld FC, Verweij CL: Evidence for the role of an altered redox state in hyporesponsiveness of synovial T cells in rheumatoid arthritis. J Immunol 1997, 158:1458-1465

60. Verweij CL, Gringhuis SI: Oxidants and tyrosine phosphorylation: role of acute and chronic oxidative stress in T-and B-lymphocyte signaling. Antioxid Redox Signal 2002 4:543-551.

61. Matsuda M, Ulfgren AK, Lenkei R, Petersson M, Ochoa AC, Lindblad S, Andersson P, Klareskog L, Kiessling R: Decreased expression of signaltransducing CD3 zeta chains in T cells from the joints and peripheral blood of rheumatoid arthritis patients. Scand J Immunol 1998, 47:254-262.

62. Isomäki P, Panesar M, Annenkov A, Clark JM, Foxwell BM, Chernajovsky Y, Cope AP: Prolonged exposure of T cells to TNF down-regulates TCR zeta and expression of the TCR/CD3 complex at the cell surface. J Immunol 2001, 166:5495-5507

63. Clark JM, Annenkov AE, Panesar M, Isomaki P, Chernajovsky Y, Cope AP: T cell receptor zeta reconstitution fails to restore responses of $T$ cells rendered hyporesponsive by tumor necrosis factor alpha. Proc Natl Acad Sci U S A 2004, 101:1696-1701

64. Krishnan S, Warke VG, Nambiar MP, Tsokos GC, Farber DL: The FcR gamma subunit and Syk kinase replace the CD3 zeta-chain and ZAP-70 kinase in the TCR signaling complex of human effector CD4 T cells. J Immuno/ 2003 170:4189-4195.

65. Laurence A, Tato CM, Davidson TS, Kanno Y, Chen Z, Yao Z, Blank RB, Meylan F, Siegel R, Hennighausen L, Shevach EM, O'shea JJ: Interleukin-2 signaling via STAT5 constrains T Helper 17 cell generation. Immunity 2007, 26:371-381.

66. Bettelli $\mathrm{E}$, Oukka M, Kuchroo VK: Th-17 cells in the circle of immunity and autoimmunity. Nat Immunol 2007, 8:345-350.

67. Niedbala W, Cai B, Liu H, Pitman N, Chang L, Liew FY: Nitric oxide induces CD4+CD25+ Foxp3 regulatory T cells from CD4+CD25 T cells via p53, IL-2, and OX40. Proc Natl Acad Sci U S A 2007, 104:15478-15483.

doi:10.1186/ar3045

Cite this article as: Nagy G, et al:: Central role of nitric oxide in the pathogenesis of rheumatoid arthritis and sysemic lupus erythematosus. Arthritis Research \& Therapy 2010, 12:210. 